\title{
Toxic organic air pollutants in the atmosphere of São Paulo and its origins: Dioxins, furans (PCDD/Fs) and polycyclic aromatic hydrocarbons (PAHs)
}

\author{
J. V. de Assunção ${ }^{1}$, C. R. Pesquero ${ }^{1}$, R. P. da Nóbrega ${ }^{1,2}$ \\ \& R. de Abrantes 1,3 \\ ${ }^{1}$ University of São Paulo, School of Public Health, \\ Department of Environmental Health, Brazil \\ ${ }^{2}$ Cummins Latin America, Brazil \\ ${ }^{3}$ Company of Environmental Sanitation Technology (CETESB), Brazil
}

\begin{abstract}
Air quality in the São Paulo Metropolitan Region has shown improvement for some pollutants such as total suspended particulate matter, and carbon monoxide, being that sulphur dioxide control has been a success, according to São Paulo State Environment Agency (CETESB) data. However, inhalable particulate and ozone still are a serious problem. Ozone levels have remained constant and have frequently exceeded air quality standards. Levels of ozone depend on the presence of organic compounds and nitrogen oxides in the air, which emissions are still increasing in the region. Besides ozone formation, organic compounds can be toxic, several of them with proven carcinogenic effect. In this work, measurements, levels and sources of dioxins, furans and polycyclic aromatic hydrocarbons were reviewed. The results show that air levels and emissions of vehicles have importance, but industry emissions in urban areas and open burning in rural areas should also be addressed; measures should be taken to reduce them. Moreover, a wider program involving these toxic substances should be implemented, and it should contain an emission inventory and an emission reduction scheme, aiming at the prevention of health effects, especially neoplasias.
\end{abstract}

Keywords: toxic pollutants, dioxins, furans, PAH, São Paul, Brazil, atmosphere. 


\section{Introduction}

Use of individual vehicles is continuously growing, but besides positive aspects caused by individual locomotion versatility, it has negative aspects like pollution, use of natural resources, and the use of urban space in streets and in car parking areas.

Stationary sources, mainly industry, also launch a great amount of pollutants to the atmosphere, including toxic pollutants, either from production processes or from fuel burning.

Emission of classical pollutants - hydrocarbons (HC), nitrogen oxides (NOx), carbon monoxide $(\mathrm{CO})$, aldehydes $(\mathrm{CHO})$ and particulate matter $(\mathrm{PM})-$ are already regulated in Brazil, to a certain extent, by the National Council on Environment - CONAMA , and by the Brazilian Institute for Environment and Protection of Renewable Natural Resources (IBAMA) [1, 2, 3]. However, hydrocarbons are a mixture of several substances, and particulate matter also can contain a great variety of compounds and some with high toxicity such as the polycyclic aromatic hydrocarbons (PAHs), polychlorinated dibenzo-p-dioxins (PCDDs), polychlorinated dibenzofurans (PCDFs) and aldehydes. In this work we will focus on PCDDs, PCDFs and PAHs that are the toxic organics of great concern at the moment.

\section{Dioxins and furans}

Polychlorinated dibenzo-p-dioxins (PCDDs) and polychlorinated dibenzofurans (PCDFs), usually known as dioxins and furans respectively, and sometimes as dioxins only, are compounds basically of anthropogenic origin, unintentionally generated, extremely persistent in the environment, having been detected in all the ambient matrices - soil, sediments, water, animals and plants. Emissions of these compounds to the atmosphere come initially from thermal processes. Out of 75 PCDDs and 135 PCDFs only 17 PCDD/Fs, the 2,3,7,8-substituted ones, are currently of interest in relation to health effects, and 2,3,7,8-TCDD is the most toxic one.

Combustion process in general, like incineration - especially of health service wastes - organic chlorine industry process, castings, steel mills, pulp and paper industry, non-ferrous metals production and recycling, especially of aluminium and copper, vehicles, oil refineries, uncontrolled open burning of biomass and of waste, forest fires, biomass and fossil fuels combustion in general are important sources of dioxins and furans $[4,5,6,7]$.

In studies carried out in animals these compounds have proven to be precursor of neoplasias, immunologic system deficiency, endocrinal disruption including diabetes mellitus, alteration in the levels of testosterone and the hormone of the thyroid, neurological damages including newborn child cognitive and behaviour alterations of mothers exposed to these compounds, damages to the liver, damages to the skin and rise of lipids in the blood, a factor of risk for cardiovascular illnesses. However, due to lack of scientific proof in the case of human beings, 16 of the 17 compounds, are classified by the IARC in group 3, 
that is, not considered as carcinogenic for human beings, even so they seem to exert teratogenic activity, and only 2,3,7,8-tetrachlorodibenzo-for-dioxin is listed as belonging to group 1, considered carcinogenic for human beings [8].

Atmospheric dispersion, deposition and subsequent accumulation in the food chain seem to be the main route of population exposure. Due to its lipofilic characteristic and stability in the environment, these compounds can accumulate in adipose tissue; consequently, foods of animal origin are those of higher concentration.

\section{Polycyclic Aromatic Hydrocarbons (PAHs)}

Polycyclic or polynuclear aromatic hydrocarbons (PAHs) constitute a subclass of the polycyclic aromatic compounds (PACs); they are organic compounds composed of two or more condensed aromatic rings that can be arranged in straight-line, angular, or cluster form. To the PAH aromatic rings some radicals can be linked to such those with five carbon atoms and those with substituted atoms (nitrogen, oxygen and sulphur). PAHs have been found in the atmosphere of urban, industrial, and rural areas. The main emission sources of PAHs are incomplete fossil fuel burning, combustion of organic substances in general, and some industrial processes such as the production of coke. The main natural PAHs sources are forest fires and volcanic activity.

In many cities of the world vehicle emissions are considered to be the most important source of PAHs to the atmosphere. Nielsen [9] reported that vehicle emissions are responsible for $90 \%$ of the PAHs associated to the particulate matter in the air of central Copenhagen. In Birmingham, United Kingdom, Dunbar et al. [10], showed that vehicle emissions are responsible for $44-93 \%$ of the amount of PAHs present in the particulate matter. In cities like Calcutta, where some industries use coal as fuel, Chattopadhyay et al. [11] showed that, concentrations of HPAs close to $200 \mathrm{ng} / \mathrm{m}^{3}$ have been found.

The knowledge of PAHs levels is important mainly due to the fact that several of them are considered carcinogenic and/or mutagenic. US.EPA [12] has identified these 16 PAHs as priority pollutants: Acenaphthene, acenaphthylene, anthracene, benzo(a)anthracene, benzo(a)pyrene, benzo(b)fluoranthene, benzo(g,h,i)perylene, benzo(k)fluoranthene, Chrysene, dibenzo(a,h)anthracene, fluoranthene, fluorene, Indeno(1,2,3-cd)pyrene, naphthalene, phenanthrene, pyrene.

\section{Air quality in metropolitan areas}

The air quality in urban regions is determined by a complex system of mobile sources (vehicles) and stationary sources (industry in special), under influence of topographic and meteorological conditions of the region.

To show the importance of vehicle emissions in the air quality of big urban centres, let us take as example the Metropolitan Region of São Paulo $(0.1 \%$ of Brazilian territory) with 39 cities and about 18 million inhabitants, concentrated mainly in 7 cities where population density is very high, with the city of São 
Paulo itself responsible for almost 11 million inhabitants (2005). Despite the region is changing from industrial to commercial and service sectors, thousands of industries are still located in this area, being the majority of them small and medium size industries, but with 2000 industries of high air pollution potential.

Nowadays vehicle emissions play a predominant role in the level of air pollution in the city of São Paulo and also in the Metropolitan Region, since industrial emissions, especially of sulphur dioxide and particulate matter, are already in a more advanced control phase [13].

In 2002 the vehicle fleet in the region was of 7.2 million vehicles, and dieselpowered vehicles account for about $6.5 \%$ of the fleet [13]. Number of cars is still increasing in the region with an addition of 200,000 cars per year in the metropolitan area and by 2015 it will reach about 9,000,000 cars and the population will reach 20.4 million inhabitants, corresponding to approximately 2.3 inhabitants per car, about the same ratio of Sao Paulo city nowadays [14]. Sao Paulo city itself is slowing down in terms of population growth and it will maintain close to 11 million inhabitants by 2015 . The region will continue to change from industrial to service sector; and transportation emissions will increase their participation in the overall air pollution levels.

Carbon monoxide levels will probably continue to go down, as less polluting new cars will substitute old cars and the expected implementation of an inspection and maintenance program. NOx and VOC control actions are slower than control actions for other pollutants. Then one can expect maintenance or increasing levels of ozone and of organic pollutants in the area for the next years. Photochemical pollution is the most complex issue and studies must be carried out before we can fully understand it, especially in this area where there is a very unique combination of fuels in the world (diesel, gasohol, ethanol, and natural gas). Inhalable particulate is another problem that must be faced.

According to Ribeiro and de Assunção [14], toxic pollutants need first an inventory of sources and a monitoring program followed by a well-planned control program, and benefits, especially on health should be addressed.

In 2004 vehicles were responsible for $98 \%$ of 1.7 million of metric tons of carbon monoxide (CO), $97 \%$ of 404 thousand metric tons of hydrocarbons (HC), $96 \%$ of 371 thousand metric tons of nitrogen oxides (NOx), 50\% of 63 thousand metric tons of particulate matter, and $55 \%$ of 38 thousand metric tons of sulphur oxides (SOx) emitted to the atmosphere in the Metropolitan Region [15].

For sulphur oxides $\left(\mathrm{SO}_{\mathrm{X}}\right)$, both industries and vehicles should be considered as important sources, and in the case of inhalable particulate $\left(\mathrm{PM}_{10}\right)$ transportation still is an important source but other sources like re-suspended soil particles and secondary aerosol formation also play an important role. In the specific case of inhalable particulate, the estimate of relative contribution of sources was obtained by receptor modelling studies done by CETESB [13].

\section{Air measurements of PAHs and PCDD/Fs in Brazil}

In Brazil, only a few studies have been done involving measurements of PAHs and PCDD/Fs in the atmosphere, the majority of them restricted to the States of Bahia, Rio de Janeiro and São Paulo. 


\subsection{Air measurements in the State of Bahia}

In a study carried out in the city of Salvador, capital of State of Bahia - Northeast of Brazil - by Pereira et al. [15] levels of the 16 priority PAHs were measured, in total suspended particulate (TSP) samples collected in a bus station on April, 1991 for 4 days (120 - 180 min sampling period), from Tuesday to Friday, during periods of heavy bus traffic, and in an urban tunnel $300 \mathrm{~m}$ long, during August, 1991 at different periods of the day. For the samples collected in the bus stop, the mean of all the seven sampling periods, for the 16 PAHs, was 42.62 $\mathrm{ng} / \mathrm{m}^{3}$, the highest concentrations occurred in the period of $6: 30 \mathrm{PM}$ (intermediary value between the initial and final sampling period), and chrysene in this period has presented the highest value $\left(26.6 \pm 8.62 \mathrm{ng} / \mathrm{m}^{3}\right)$ in relation to all periods. In the urban tunnel, in six samples collected, pyrene concentration presented the highest mean level $\left(79.4 \pm 11.5 \mathrm{ng} / \mathrm{m}^{3}\right)$ followed by fluoranthene $\left(39.0 \pm 5.2 \mathrm{ng} / \mathrm{m}^{3}\right)$ with a mean of $234.38 \mathrm{ng} / \mathrm{m}^{3}$ for the sum of 16 PAHs.

\subsection{Air measurements in the State of Rio de Janeiro}

In the state of Rio de Janeiro, a study involving day-time concentrations of 15 PAHs in total suspended particulate samples collected in traffic routes of the cities of Rio de Janeiro and Niterói was carried out by Pereira Neto et al. [16] in the summer of 1999. In this study the results showed sums of $15 \mathrm{PAH}$ concentrations of 22.5 and $24.4 \mathrm{ng} / \mathrm{m}^{3}$ in Rio de Janeiro $(10 \mathrm{~km}$ far from downtown Rio de Janeiro in an important traffic route to the central area), while in Niterói the results showed sums of $15 \mathrm{PAH}$ concentrations in the range of 5.48 to 7.88 with an average of $6.78 \mathrm{ng} / \mathrm{m}^{3}$. Individual PAH concentrations were systematically lower in Niterói $\left(0.03\right.$ to $\left.1.45 \mathrm{ng} / \mathrm{m}^{3}\right)$ than in Rio de Janeiro $(0.13$ to $4.10 \mathrm{ng} / \mathrm{m}^{3}$ ).

In the city of Campos dos Goytacazes, with about 400,000 inhabitants, located northeast of the city of Rio de Janeiro, the seasonal variation of the PAHs was evaluated by Azevedo et al. [17], in the total suspended particulate (24-hour Hi-vol samples) collected in a period of one year (December 1996 to November 1997) in three sites (downtown, suburbs and rural area). Results showed that concentrations have varied from 9.31 to $341.9 \mathrm{ng} / \mathrm{m}^{3}$ in the central area, from 1.03 to $312.09 \mathrm{ng} / \mathrm{m}^{3}$ in the suburban area, and from 0.12 to $165.2 \mathrm{ng} / \mathrm{m}^{3}$ in the rural area. The highest concentrations were observed from May to September, and probably influenced by emissions from pre-harvest burning of sugar cane plantations.

With relation to PCDD/PCDFs measurements done in 1995 in the cities of Barra Mansa, Cantagalo, Santa Cruz and Volta Redonda, the results showed concentrations in the range of 3 to $994 \mathrm{fg} \mathrm{I}-\mathrm{TEQ} / \mathrm{m}^{3}$ according to PNUMA report [18]. The highest concentration was observed in the city of Santa Cruz (994 $\mathrm{fg} \mathrm{I-TEQ} / \mathrm{m}^{3}$ ), followed by the city of Barra Mansa (839 $\mathrm{fg} \mathrm{I-TEQ} / \mathrm{m}^{3}$ ), and the lowest was observed in the city of Volta Redonda ( $\left.3 \mathrm{fg} I-T E Q / \mathrm{m}^{3}\right)$, even though this city has the oldest and one of the largest steel mill plant in Brazil. 


\subsection{Air measurements in the State of São Paulo}

In a study carried out in 1995 and 1996, by CETESB [19] in a joint work with the University of Tübingen - Germany, toxic organic compounds including $\mathrm{PCDD} / \mathrm{Fs}$ and PAHs were analysed in different environmental matrices, including air, in the cities of São Paulo, Araraquara (inland São Paulo), and Cubatão (located on the coastline, and an area of heavy industries). Concentration levels of PAHs varied from 413 to $1.794 \mathrm{ng} / \mathrm{Nm}^{3}$ in the city of Araraquara (highest concentrations were observed in periods of pre-harvesting burning of sugar cane plantation), from 33 to $167 \mathrm{ng} / \mathrm{Nm}^{3}$ in the city of Cubatão, and from 38 to $136 \mathrm{ng} / \mathrm{Nm}^{3}$ in the city of São Paulo. PCDD/Fs levels in the city of Araraquara varied from 16 to $267 \mathrm{fg} \mathrm{I-TEQ} / \mathrm{Nm}^{3}$, the lowest concentrations were observed in a period of no pre-harvesting burning sugar cane plantation, and the highest concentrations were observed in periods of pre-harvesting burning of sugar cane plantation. In the city of Cubatão PCDD/Fs concentrations

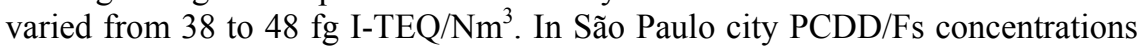
varied from 86 to $169 \mathrm{fg} \mathrm{I}-\mathrm{TEQ} / \mathrm{Nm}^{3}$.

In a more recent study carried out by de Assunção et al. [20], from November 2000 to August 2001, levels of PCDD/Fs in the atmosphere of the city of São Paulo were measured simultaneously in three distinct areas using PUF samplers and 24-hour sampling time, and one-day sampling in each season; solid phase was analysed jointly with gaseous phase collected in a PUF filter. The results showed concentrations in the range of 47 to $187 \mathrm{fg} \mathrm{I-TEQ} / \mathrm{m}^{3}$ in a urban area under the influence of vehicle emissions, from 63 to $223 \mathrm{fg} \mathrm{I-TEQ} / \mathrm{m}^{3}$ in an urban area under influence of vehicle emissions and influenced partially by health service waste incinerator emissions, and from 47 to $751 \mathrm{fg} \mathrm{I-TEQ} / \mathrm{m}^{3}$ in an area under the influence of industrial and heavy traffic emissions. The authors concluded that there are similarities in the distribution of individual congeners in the three urban sites. Principal component analysis showed that all the variables are highly correlated with one another except the 2,3,7,8-TCDD one; multivariate analysis showed that in the site with higher concentrations that is under the influence of industrial and heavy traffic emissions showed contribution of different emission sources. At the other two sites, vehicular traffic seems to be the main source. The authors also compared the results with the levels of several cities in the world and concluded that the air levels in São Paulo city need attention, and recommended further investigation for a better understanding of the emission sources of these pollutants in air., and have proposed a long-term monitoring to elucidate the relationship between emissions of these pollutants from primary anthropogenic sources, such as diesel, gasoline and alcohol engines.

In a study carried out by de Martinis et al. [21], in $\mathrm{PM}_{10}$ 24-hour samples collected once every 6 days from the $10^{\text {th }}$ February to the $30^{\text {th }}$ May of 1994 , in a site located in a central and residential/commercial area with heavy vehicular traffic, 17 PAHs compounds were analysed. Results presented sum of 17 PAHs concentrations of $95.5 \mathrm{ng} / \mathrm{m}^{3}$. 
Measurements of PAHs, from phenanthrene to benzo(g,h,i)perylene, in total suspended particulate matter also collected in the atmosphere of São Paulo city were performed by Vasconcellos et al. [22], in 24-hour sampling time by using high volume samplers, in the winter of 2000, in three sites, simultaneously. They have found average concentrations of $3.10 \mathrm{ng} / \mathrm{m}^{3}$ at the University of São Paulo urban campus, $2.73 \mathrm{ng} / \mathrm{m}^{3}$ in an urban area with dense vegetation, and $1.92 \mathrm{ng} / \mathrm{m}^{3}$ in a forest area (Atlântica forest) with minimal impact from anthropogenic sources. Overall the results showed low PAHs levels due to rainfall episodes during the sampling period. In this study Vasconcellos et al. [22] also measured the 2-hour period concentrations of the same PAHs in two urban tunnels, one only allowed for light duty vehicles (JQ) and the other one allowed for all type of vehicles (MM). Total PAH concentrations varied from 1.61 to $2.66 \mathrm{ng} / \mathrm{m}^{3}$ in the JQ tunnel and from 1.31 to $1.42 \mathrm{ng} / \mathrm{m}^{3}$, in the MM tunnel.

\subsection{Measurements in the exhaust of vehicles}

In relation to PAHs and PCDD/Fs measurements in vehicle emissions only two studies have been found in the literature.

The first one was done by Abrantes et al. [23] using vehicles from São Paulo city fleet; they have evaluated 14 PAHs (naphthalene, acenaphthene, fluorene, phenanthrene, anthracene, fluoranthene, pyrene, benzo(a)anthracene, chrysene, benzo(b)fluoranthene, benzo(k)fluoranthene, benzo(a)pyrene, dibenzo(a,h)anthraxcene, benzo(ghi)perilene) in the exhaust of 4 light-duty commercial diesel vehicles, namely 3 vans and 1 pick-up, running in a chassis dynamometer, using US FTP75 procedure. The pollutants were analysed in both solid and gaseous phases by high performance liquid chromatography (HPLC). The results showed total PAH concentrations in the range of 1.133 to $5.801 \mathrm{mg} / \mathrm{km}$. Naphthalene, phenanthrene, fluoranthene, pyrene and chrysene were detected in all tests.

Analysis of PCDD/Fs in the exhaust of new diesel-powered engines was carried out by Nóbrega et al. [24], using 13-point ECE cycle procedure and standard diesel fuel, using a work-bench dynamometer. Particulate matter was collected in all tests; in some tests gaseous phase was also collected in polyurethane foam (PUF); both samples (filters and PUF) were jointly analysed by US-EPA method 8290. Results showed that, in general, dioxins and furans concentrations were under the detection limit of the method, which is $3.87 \mathrm{pg}$ $\mathrm{TEQ} / \mathrm{m}^{3}$. In only one sample OCDD and $1,2,3,4,6,7,8-\mathrm{HpCDF}$ were detected, but just above the detection limit.

\section{Final considerations}

This work shows that Brazil has scarce information about levels of PAHs and PCDD/Fs in the air and in vehicle emissions. Nevertheless, existing data on these classes of pollutants demonstrate that high levels can exist in urban, industrial and rural areas with pre-harvest burning of agricultural plantations. 
Considering the aspect of public health protection, it is important to develop a control program involving toxic substances in general, the determination of national emission factors, to carry on an emission inventory, and the setting of priorities and an emission reduction schedule, aiming at the reduction of air pollution levels and consequently health effects to the population, in special the occurrence of neoplasias.

The so wide range of levels observed shows the necessity to collect more data with comparable methodologies and similar sampling periods. Our research group is continuing to work in this direction; we are now developing another study involving all these pollutants, in relation to Otto and Diesel vehicle emissions and new measurements in the atmosphere of São Paulo city.

The automotive area already has a schedule for the reduction of emissions of classic pollutants and aldehydes, as regulated by the National Council on Environment (CONAMA) but the necessity of regulating toxic substances still remains. There is also the necessity of increasing national competence for the collection and analysis of organics, especially in relation to dioxins and furans that needs high-resolution gas chromatography and high-resolution mass spectrometry. At the present time analysis of dioxins and furans by $\mathrm{HRGC/HRMS}$ in Brazil is available only in one laboratory. In 2004 Brazil [25] has also adhered to the Stockholm Convention on Persistent Organic Pollutants (POPs) and this will push control programs and will increase the need of more competence in this area.

Finally we acknowledge to the São Paulo State Foundation for Financial Support to Research (FAPESP) for the financial support given to two studies already concluded and to one in progress, which includes a complete GC/MS system for PAH analysis, already operational.

\section{References}

[1] Brazil. Resolução CONAMA n. 18. Diário Oficial da União, 1986.

[2] Brazil. Portaria IBAMA n. 1937. Diário Oficial da União, 1990.

[3] Brazil. Resolução CONAMA n. 8. Diário Oficial da União, 1993.

[4] Kouimtzis, T.h., Samara, C., Voutsa, D., Balafoutis, C.H., \& Müller, L. $\mathrm{PCDD} / \mathrm{Fs}$ and PCBs in airborne particulate matter of greater Thessaloniki area, N. Greece. Chemosphere 47, pp. 193-205, 2002.

[5] Mukerjee, D. Health impact of polychlorinated dibenzo-p-dioxins: A critical review. J Air Waste Manage Assoc 48, pp. 157-165, 1998.

[6] De Assunção J.V. \& Pesquero, C.R. Dioxinas e furanos: origens e riscos. Rev Saúde Publica; 33, pp. 523-530, 1999.

[7] United Nations Environment Programme (UNEP), Standardized Toolkit for Identification of Dioxin and Furan Releases. UNEP Chemicals: Geneva, February 2005. www.chem.unep.ch/pops

[8] International Agency for Research on Cancer [IARC]. Monographs on The Evaluation of Carcinogenic Risks to Humans. Vol 69. Polychlorinated dibenzo-para-dioxins and polychlorinated dibenzofurans. IARC: Lyon, 1997. 
[9] Nielsen T. Traffic Contribution of Polycyclic Aromatic Hydrocarbons in the Center of a Large City. Atmos Environ 30(20), pp. 3481-90, 1996.

[10] Dunbar, J.C., Lin, C-I., Vergucht, I., Wong, J. \& Durant, J.L. Estimating the contributions of mobile sources of PAH to urban air using real-time PAH monitoring. Sci. Total Environ. 279, pp. 1-19, 2001.

[11] Chattopadhyay, G., Samanta, G., Chatterjee, S. \& Chakraborti, D. Determination of particulate phase polycyclic aromatic hydrocarbons in ambient air of Calcutta for three years during winter. Environ Technol. 19 pp. 873-882, 1998.

[12] United States Environmental Protection Agency. Office of Air Quality Planning and Standards, Handbook for Air Toxics Emission Inventory Development - Volume I: Stationary Sources, US.EPA Research Triangle Park, NC. Nov 1998. (EPA-454/B-98-00)

[13] Companhia de Tecnologia de Saneamento Ambiental (CETESB), Relatório de Qualidade do Ar no Estado de São Paulo 2004. CETESB: São Paulo, 2005 www.cetesb.sp.gov.br

[14] Ribeiro, H. \& de Assunção, J.V., Transport air pollution in São Paulo, Brazil: advances in control programs in the last 15 years (Chapter 6). Advance in City Transport: Case Studies, ed. C. Basbas, WIT Press: England, 2005.

[15] Pereira, P.A., Andrade, J.B. \& Miguel, A.H., Measurements of semivolatile and particulate polycyclic aromatic hydrocarbons in a bus station and an urban tunnel in Salvador, Brazil. J Environ Monit, 4 pp. 558-561 2002.

[16] Pereira Netto, A.D., Barreto, R.P., Moreira, J.C. \& Arbilla G., Preliminary Comparison of PAH in Total Suspended Particulate Samples Taken at Niteroi and Rio de Janeiro Cities, Brazil. Bull Environ Contam Toxicol., 6 pp. 36-43, 2001.

[17] Azevedo, D.A., Santos, C.Y.M. \& Aquino Neto, F.R., Identification and seasonal variation of organic matter in aerosols from Campos dos Goytacazes area, Brazil. Atmos Environ. 36 pp. 2383-2395, 2002.

[18] Programa de las Naciones Unidas para el Médio Ambiente (PNUMA), Evaluación Regional sobre Sustâncias Tóxicas Persistentes - Informe Regional de Sudamérica Oriental y Occidental. PNUMA: diciembre de 2002. (www.chem.unep.ch/pts/regreports), 2002.

[19] Companhia de Tecnologia de Saneamento Ambiental (CETESB), Avaliação de compostos orgânicos provenientes da queima de palha de cana-de-açúcar na região de Araraquara e comparação com medições efetuadas em São Paulo e Cubatão. Relatório Final. CETESB: São Paulo, 2002. www.cetesb.sp.gov.br

[20] De Assunção, J.V., Pesquero, R.C., Bruns, R.E. \& Carvalho L.R.F., Dioxins and furans in the atmosphere of São Paulo city, Brazil. Chemosphere, 58(10), pp. 1391-1398, 2005.

[21] De Martinis, B.S., Okamoto, R.A.B., Kado, N.Y., Gundel, L \& Carvalho, L.R.F., Polycyclic aromatic hydrocarbons in a bioassay-fractioned extract 
of $\mathrm{PM}_{10}$ collected in São Paulo, Brazil. Atmos Environ., 36, pp. 307-314, 2002.

[22] Vasconcellos, P.C., Zacarias, D., Pires, M.F.A., Pool, C.S. \& Carvalho LRF., Measurements of polycyclic aromatic hydrocarbons in airborne particles from the metropolitan area of São Paulo City, Brazil. Atmos Environ., 37, pp. 3009-3018, 2003.

[23] Abrantes, R., de Assunção J.V. \& Pesquero, C.R., Emission of polycyclic aromatic hydrocarbons from light-duty diesel vehicles exhaust. Atmos Environ., 38, pp. 1631-1640, 2004.

[24] Nobrega, R.P., de Assunção, J.V. \& Pesquero, C.R., Levels of Dioxins and Furans in the Particulate Matter of Heavy Diesel Motors. Proc. of the $96^{\text {th }}$ Conference and Exhibition of the Air \& Waste Management Association. AWMA: Pittsburgh, 2003. (Cd-rom)

[25] Brazil. Decreto legislativo n. 204. Diário Oficial da União, May 5th, 2004. 